\title{
Trace fossils from the Desejosa Formation (Schist and Greywacke Complex, Douro Group, NE Portugal): new Cambrian age constraints
}

\author{
Í. DIAS DA SILVA' ${ }^{1}$ S. JENSEN² ${ }^{2}$ E. GONZÁLEZ-CLAVIJO' \\ 'Instituto Geológico y Minero de España \\ Azafranal 48, 37001 Salamanca, Spain. Dias Da Silva Email: ipicaparopo@gmail.com. Phone number: +34637420747 \\ González-Clavijo Email: e.clavijo@igme.es
}

2Área de Paleontología, Facultad de Ciencias, Universidad de Extremadura 06006 Badajoz, Spain. Email: soren@unex.es

\section{A B S T R A C T}

Trace fossils from a new locality in the Desejosa Formation, Freixo de Espada à Cinta area, northeast Portugal, are described, including Teichichnus rectus and the first Cambrian record from Iberia of the ichnogenus Rosselia, identified as R. cf. socialis. A literary review of the Cambrian record of Rosselia reveals no occurrences older than Cambrian Age 3. The occurrence of Rosselia in the Desejosa Formation therefore adds evidence to that of earlier reports on trilobite remains from the upper part of the Desejosa Formation for a Cambrian age of this unit. Both Rosselia and Teichichnus are zindicative of the Cruziana ichnofacies, which is representative of a shallow-marine depositional environment, consistent with earlier interpretations for the depositional conditions of the upper part of the Desejosa Formation in this sector, and in the equivalent Cambrian units in Spain..

KEYWORDS $\quad$ Trace fossils. Rosselia socialis. Teichichnus rectus. Early Cambrian. Iberian Massif. Douro Group.

\section{INTRODUCTION}

Previous stratigraphic and paleontological studies (trace and body fossils) on the Spanish pre-Ordovician record of the Central Iberian Zone (CIZ) demonstrate that the age of the sequence is latest Ediacaran (Vidal et al., 1994a, b; Cortijo et al., 2010) to early Cambrian (e.g. Brasier et al., 1979; Díez Balda, 1986; San José et al., 1990; Gozalo et al., 2003; Díez Balda et al., 2004; Rodríguez Alonso et al., 2004; Jensen et al., 2010).

In Portugal, the pre-Ordovician stratigraphic units of the CIZ are grouped in the Schist and Graywacke Complex (Complexo Xisto-Grauváquico in Portuguese; Carrington da Costa, 1950; Teixeira, 1955) which has been classically divided into the Beiras and Douro groups (Sousa, 1982, 1984). The precise stratigraphic relationship between these two groups remains uncertain but recent studies suggest that at least portions of these units are time equivalent and they are late Ediacaran and Cambrian (e.g. Pereira et al., 2006; Pereira et al., 2012b). In the CaramuloBuçaco region (Portugal) a succession attributed to the Beiras Group contains trace fossils identified as Planolites sp. and Phycodes? n. sp (Gámez Vintaned, personal communication in Medina et al., 1998). The Phycodes-like morphology suggests an age younger than ca. 550Ma (cf. Jensen, 2003), consistent with the maximum depositional age of $549.6 \pm 4.4 \mathrm{Ma}(\mathrm{U}-\mathrm{Pb}$ in detrital zircons; Pereira et al., 2012b) from approximately the same stratigraphic interval. From the base, the Douro Group consists of the Bateiras, Ervedosa, Rio Pinhão, Pinhão, Desejosa and São Domingos formations. Sousa (1984) cited Planolites from the Pinhão Formation and suggested an age of less than 560Ma approximately. A younger age for the whole succession (<550Ma) can be expected if we adopt the correlation proposed by Sousa $(1983 b, 1984)$ of the 
carbonate-bearing Bateiras Formation with the Cloudinarich units (Vidal et al., 1994a) in the Salamanca province (Spain). Trace fossils have been reported as locally common in the Desejosa Formation (e.g. Coke, 2000; Coke et al., 2000) though without published detail to date. At present time, evidence for a Cambrian (or younger) age for the upper part of the Desejosa Formation is based on poorly preserved indeterminable trilobites (Rebelo and Romano, 1986), and its geochemical profile is also consistent with Cambrian age (Dias da Silva et al., 2011; Dias da Silva, 2014).

The first detailed documentation of trace fossils from the Desejosa Formation is here presented on the basis of material collected from a new trace fossil locality (Dias da Silva, 2014). These include Teichichnus rectus and some of the best preserved Cambrian material of Rosselia to date, providing important new age constraints on the Desejosa Formation, and also giving valuable information about the depositional setting of the Desejosa Formation. The regional stratigraphic implications of these new data are also discussed in the CIZ context.

\section{GEOLOGICAL SETTING}

The Iberian branch of the European Variscan Massif has been traditionally divided into several geological zones (Lotze, 1945; Julivert et al., 1972). On historical grounds these divisions were based mainly on stratigraphic features, but tectonic, magmatic and metamorphic characteristics were also considered. The Central Iberian Zone (CIZ), in its current definition (Julivert et al., 1972), is the most extensive zone in the Iberian Massif (Fig. 1).

It has been subdivided in several domains in Spain (Pérez-Estaún et al., 2004) and Portugal (Dias et al., 2006). One of its most outstanding stratigraphic features

FIGURE 1. Location of the studied area in the Iberian Massif (adapted from Pérez-Estaún et al., 2004). is the presence of a thick $(>5 \mathrm{~km})$ and widespread basal metassedimentary unit known as the Schist and Greywacke Complex. It generally displays a (very) low metamorphic grade and little deformation, which allows the identification of the original lithologies and primary sedimentary structures thus suggesting a turbiditic nature for much of this sequence. The scarcity of lithological marker beds and fossil content has resulted in a poorly constrained age and an uncertain regional correlation. Several regional lithostratigraphic units have been established being recognized a general upward-shallowing environment from basinal and slope to platform deposits (e.g. Díez Balda, 1986; San José et al., 1990; Vidal et al., 1994a, b; Valladares et al., 2002). The age of the oldest part of the Schist and Graywacke Complex remains poorly known, nevertheless the earlier suggestions of a "Riphean" age (>650Ma) were based on microfossils without age significance, and the entire succession is now thought to be Ediacaran and younger (e.g. Pereira et al., 2012a,b).

The studied region is located next to the Douro River canyon which is the north-eastern border between Spain and Portugal for more than $100 \mathrm{~km}$, providing an impressive natural cross-section of the northern Central Iberian Zone. Recent geological survey in this area has resulted in new stratigraphic and ichnologic data (Fig. 2; Dias da Silva, 2014). In the northern and central part of the canyon, sedimentary features of the older rocks are largely obliterated due to pervasive Variscan deformation which resulted in a high-temperature and low-pressure metamorphism (Escuder Viruete et al., 1994, 2000; Dias da Silva, 2014). The southern sector, near Freixo de Espada à Cinta (Portugal), shows more favourable conditions with well-preserved sedimentary structures and trace fossils. The geological structure of this area is mainly composed of cartographic-scale upright folds belonging to the late Variscan regional event (Fig. 2). The Desejosa Formation is extensively exposed in the region and has been affected by only very low metamorphism and gentle deformation during the Variscan Orogeny, which has made it possible to build up a synthetic stratigraphic column of the infraOrdovician rocks, unveil the tectonic structure, and position the trace fossils described here inside the sedimentary sequence (Fig. 2). The Desejosa Formation was first described by Sousa (1982, 1983b). It typically consists of millimetre- to centimetre-scale alternations of generally parallel-laminated lutites and fine-grained sandstone, resulting in a striped appearance. The most common sedimentary structures are graded bedding and load-structures. More rarely there are greywacke beds up to half a metre thickness. In the study area, the Desejosa Formation consists of a terrigenous sequence more than $300 \mathrm{~m}$ thick, which displays thin beds of black slates and sandstones, the latter frequently showing 


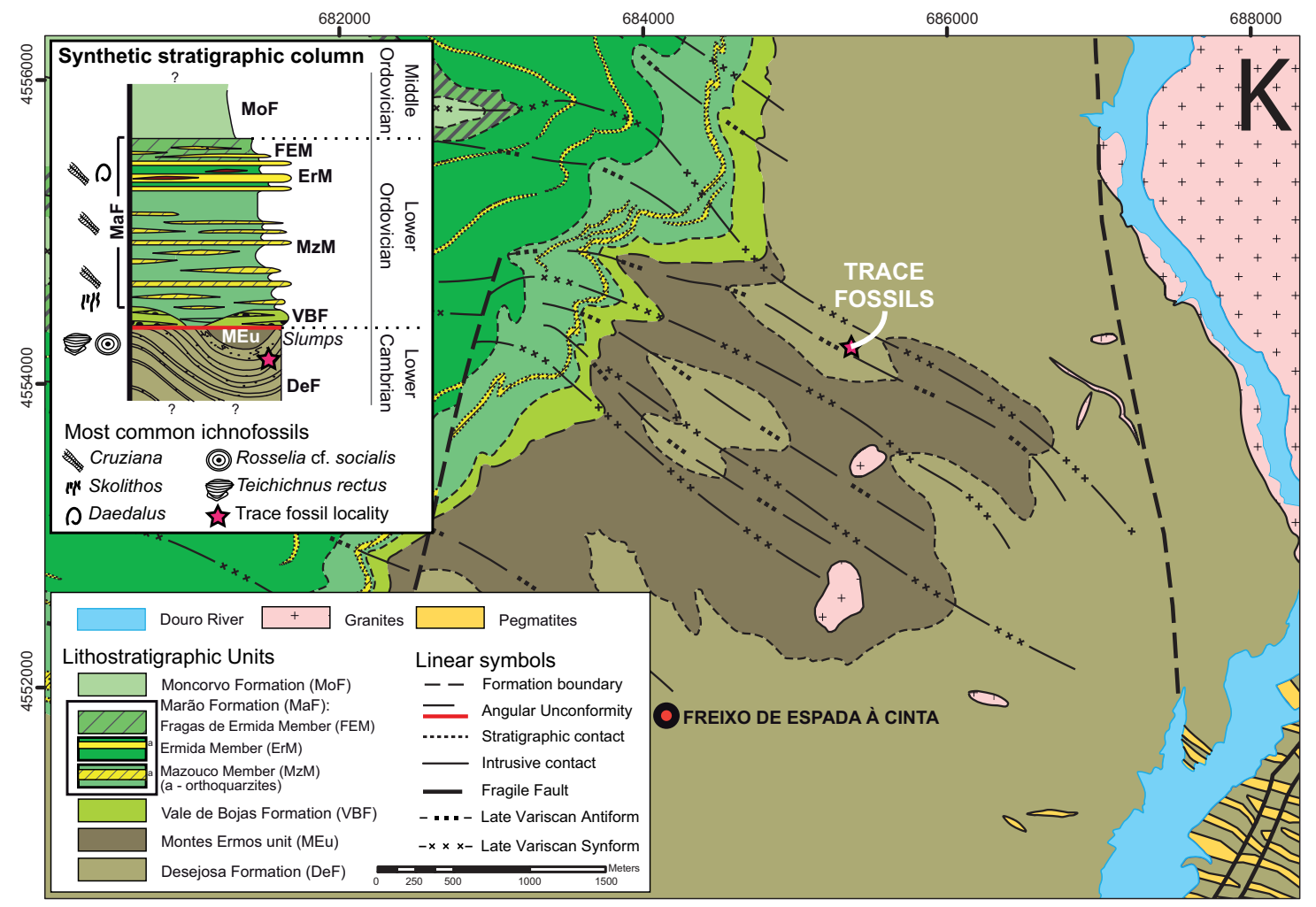

FIGURE 2. Schematic geological map of the eastern border of the Moncorvo Synform, near Freixo de Espada à Cinta (northeast Portugal) with the location of the studied trace fossils (dark grey star). In the top-left corner inset the local synthetic stratigraphic column with the stratigraphic position of the site is displayed. Coordinate tags each 2000m (UTM-ED1950, 29N). Modified from Dias da Silva (2013) and form the 1:50.000 geologic map № 422 (Aldeadávila de la Ribera, Escuder Viruete et al., 2000) of the Spanish National Geological Survey (IGME).

bioturbation and sedimentary structures. Some scarce and thin discontinuous beds of calc-silicate rocks and carbonates are referred in Ferreira da Silva and Ribeiro (1994). The uppermost beds (40m) present slump structures (Fig. 2, synthetic column), broken beds and microconglomeratic levels. The trace fossils described here were recently identified in the Freixo de Espada à Cinta area (Fig. 2) in a location that could be estimated at about $100 \mathrm{~m}$ below the top of Desejosa Formation. The intensive bioturbation suggests a shallow depositional environment as was proposed for the upper part of the Douro group by Sousa (1982).

Concordantly overlying the Desejosa Formation, a new informal unit has been defined and mapped. It was first named Mazouco Formation (Dias da Silva et al., 2011) after a small village which however is located out of the exposure. For this reason we propose to change the name to Montes Ermos unit, after a small hill located well inside the exposure of this lithostratigraphic unit (Dias da Silva, 2014). The Montes Ermos unit, with a thickness greater than $150 \mathrm{~m}$, is roofed by the Ordovician basal unconformity. It occupies the nucleus of a late Variscan first order synform also folding the Ordovician and Silurian age units (Moncorvo Synform, Fig. 2). In a small area (around Montes Ermos hill) it contains small cordierite blasts related to Variscan granitic stocks. This unit is made up of a monotonous sequence of grey fine-grained sandstone and siltstone beds ranging from 60 to $120 \mathrm{~cm}$. The boundaries between beds are marked by dark millimetre-thick layers displaying iron oxide when weathered. No fossils have been found in this unit.

The above described are the only lithostratigraphic units of the Schist and Graywacke Complex in the eastern portion of the Moncorvo Synform. The São Domingos, Pinhão and Rio Pinhão Formations as defined by Sousa (1984) were not identified here. The upper limit of the Douro Group is the regional angular unconformity known as Toledanic (e.g. Gutiérrez Marco et al., 1990), underlying the Lower Ordovician stratigraphic units of the Vale de Bojas and Marão Formations (Sá et al., 2005; Dias da Silva, 2014).

\section{DESEJOSA FORMATION TRACE FOSSILS}

A new ichnofossil locality in the Desejosa Formation was found about $3.5 \mathrm{~km} \mathrm{NE}$ of Freixo de Espada à Cinta village (Fig. 2). The trace fossils are observed on weathered bedding-planes (Figs. 3A; 5D-E) on both sides of a small valley with a moderately good geological exposure. 

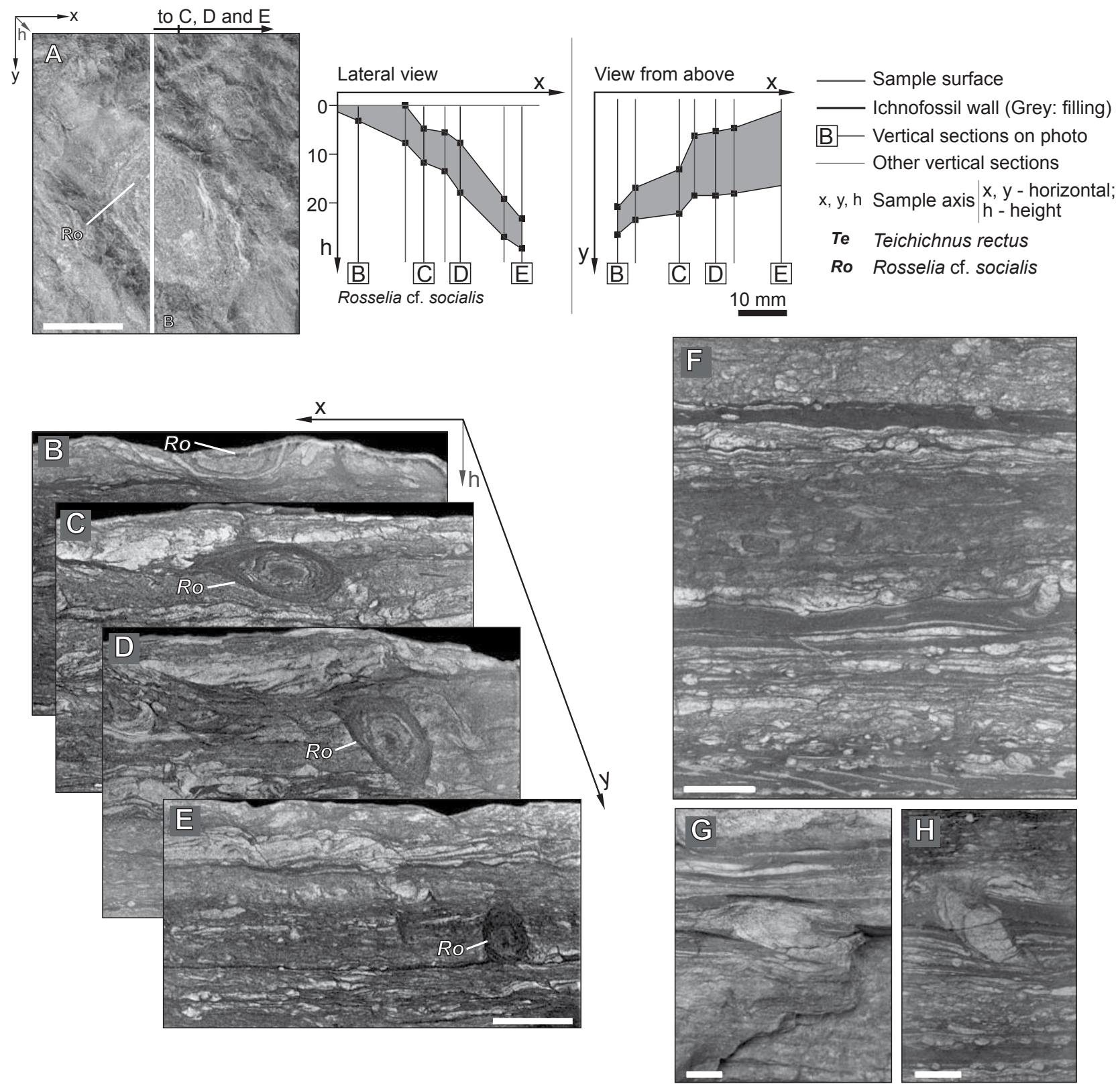

FIGURE 3. Trace fossils from the Desejosa Formation (locality in Fig. 2). A) Top view of Rosselia cf. socialis showing concentric lamellae. Diagrams show the vertical and horizontal track of this ichnogenus (lateral view and view from above, respectively) taken from the study of a sequence of seven vertical sections (represented by thin lines, including sections represented in the photos B to E); B-E) Vertical sections through the Rosselia cf. socialis represented in A; F) Typical example of bioturbation found in this locality; G-H) Inclined plug-shaped burrows (Teichichnus rectus?) showing lateral displacement. Scale bar represents $10 \mathrm{~mm}$ in all the pictures.

\section{Trace fossil description}

In order to obtain 3D views of the ichnofossil, vertically oriented parallel sections were produced with a rock-saw to show the disruption of primary sedimentary bedding by burrowing animals, including oblique sand-filled plugs with evidence for lateral displacement or short plugshaped burrows. Only two ichnogenera were noteworthy of a detailed description in the sectioned material, namely Rosselia Dahmer, 1937, and Teichichnus Seilacher, 1955.

\section{Ichnogenus Rosselia Dahmer, 1937}

Rosselia cf. socialis Dahmer, 1937 (Figs. 3A-E, 4D-G, 5A, D-F)

Description. Trace fossils with a vertical or oblique orientation made up of irregularly spaced and wavy alternations of dark (muddy) and light (micaceous siltstone) concentric laminae (Fig. 3D, G), or with pronounced siltstone laminae (Fig. 4D). Vertical sections 

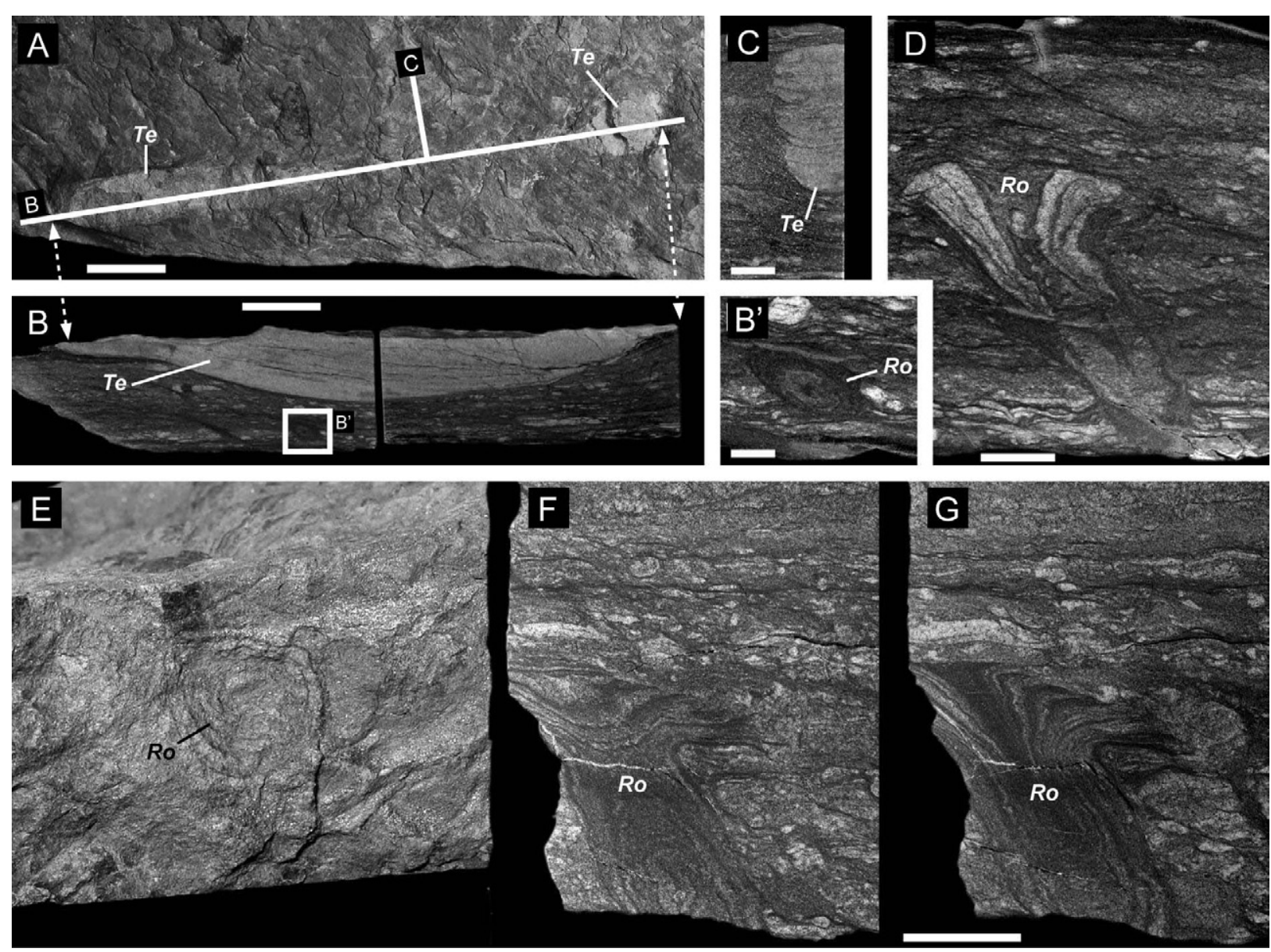

FIGURE 4. Trace fossils from the Desejosa Formation (locality in Fig. 2). A-C) Top (A) and lateral views (B and C) of a Teichichnus rectus. Scale bars in A and B represent $20 \mathrm{~mm}$. Scale bar in C represents $5 \mathrm{~mm}$; B' Close-up of Rosselia cf. socialis located left to centre in lower part of B. Scale bar represents $5 \mathrm{~mm}$; D) Vertical section showing a conical burrow with pronounced sand-dominated concentric lamination surrounding a broad central region (Rosselia cf. socialis). Scale bar represents 5mm; E-G) Top (E) and vertical sections (F and G) of a Rosselia cf. socialis. Scale bar represents $10 \mathrm{~mm}$.

show elongated cone-shaped burrows, some being approximately cylindrical, 10 to $20 \mathrm{~mm}$ wide and up to $30 \mathrm{~mm}$ long (representing incomplete specimens). The horizontal section presents ovate or circular shapes (Fig. $5 \mathrm{E}, \mathrm{F}$ ) with a narrow mud or sand-filled central shaft (Fig. $5 \mathrm{~F})$. In some cases it was possible to see signs of vertical repetition of the burrowing (Fig. 4G).

Discussion. The assignation of this material to Rosselia is based in the general conical-shaped burrows with concentric laminae that surround a central shaft (sandy or muddy). The relationship between Rosselia and Cylindrichnus has been discussed by numerous authors (e.g. Frey and Howard, 1985; Nara, 1995; Uchman and Krenmayr, 1995), leading to the differentiation of both genera with Rosselia presenting conical to irregularly bulbous concentric lamellae and Cylindrichnus showing vertical to horizontal cylindrical or sub-cylindrical burrows (Frey and Howard, 1985). However, recent studies suggest that the type material of Cylindrichnus concentricus consist of U-shaped or bow-shaped burrows (see Belaústegui and Gibert 2013, for dicussion), calling into question the identification of earlier reports of this ichnogenus. Vertical repetition in Rosselia probably represents examples of equilibrichnia ( $c f$. Nara, 1997). Cretaceous and younger Rosselia typically have a spindle-shaped burrow-form, with conical forms as the result of erosional truncation (Nara, 1995). This is also seen in the type material of Rosselia socialis from the Devonian of Germany (Dahmer, 1937; Schlirf et al., 2002). In both cases the central portion of Rosselia socialis often is sand-filled. Another related form is Asterosoma von Otto, 1854, with concentrically layered horizontal or inclined burrows that radiate from a central point. Asterosoma has been described from the middle Cambrian of Jordan (Hofmann et al., 2012), but no evidence for a radiate arrangement has been observed in the Desejosa Formation material.

The concentric lamellae observed in the Desejosa Formation materials are closely compared with the reports 

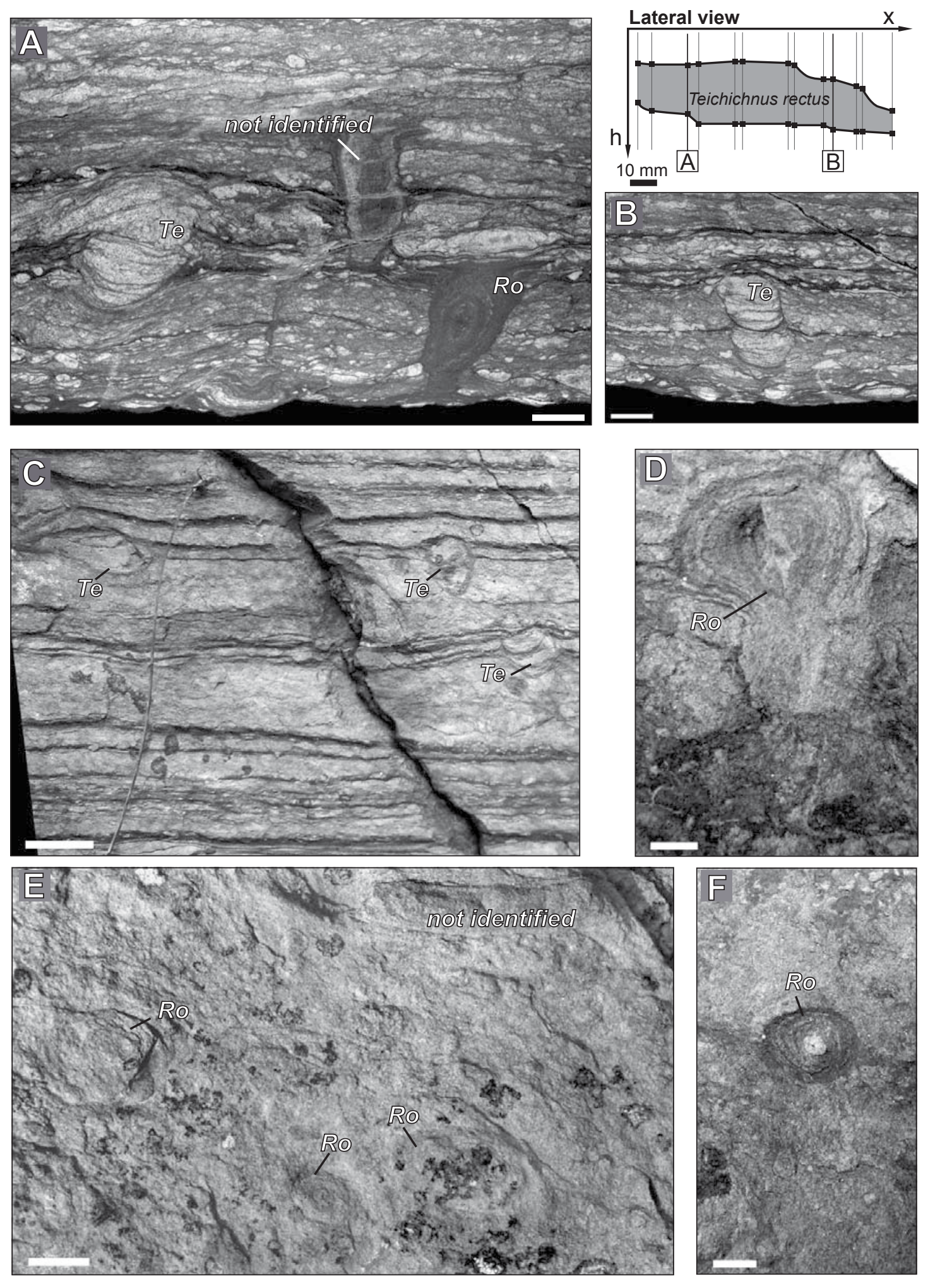

FIGURE 5. Trace fossils from the Desejosa Formation. A-B) Vertical sections through a slab with a Teichichnus rectus, with position of sections indicated in the lateral view diagram (taken from a sequence of thirteen vertical sections, including the sections represented in A and B). Near the right margin of A a mud-dominated Rosselia cf. socialis occurs, with indication for truncation. The trace fossil near the centre shows a sand-rich mantle surrounding a faintly developed concentric lamination. Scale bar in B represents 10mm (same scale as A); C) Field photograph showing bedding and several specimens of Teichichnus rectus. Scale bar represents $20 \mathrm{~mm}$; D) Field photograph of top bedding-plane view of a Rosselia cf. socialis. Scale bar represents $5 \mathrm{~mm}$; E) Field photograph of a weathered (and partly lichen-covered) top bedding-plane view with several poorly preserved Rosselia cf. socialis. Scale bar represents $10 \mathrm{~mm}$; F) Field photograph of top bedding-plane view of a Rosselia cf. socialis with a sand-filled central shaft. Scale bar represents $5 \mathrm{~mm}$. 
of Rosselia socialis, differing only in the predominantly mud-filled nature of the central shaft in this locality (only one specimen is sand filled; Fig. 5F). We consider that this difference is a reflection of the depositional conditions which created thin intercalations of sand, silt and mud beds, and therefore it does not present ichnotaxonomic significance. Well-developed specimens of Rosselia socialis are spindleshaped, with conical forms being the result of erosional truncation. Because of the lack of evidence for spindleshaped forms in the Desejosa Formation, this material is assigned to Rosselia cf. socialis. The Rosselia in Figure 4 $\mathrm{D}, \mathrm{F}$ and $\mathrm{G}$ shows some similarity with burrows that Mata et al. (2012) interpreted as equilibrichnia behavior of sea anemones. Because the studied material always presents multiple concentric laminations with a mud or sandy central shaft and not a simple cylindrical burrow with a central shaft, the Desejosa material is better assigned to Rosselia than to plug-shaped burrows such as Bergaueria, Conichnus, or Dolopichnus.

The exact process by which the concentric lamination in Rosselia is formed is not well understood, although Cenozoic specimens, in particular, have been related to the feeding activity of terebellid polychaetes (i.e. Nara, 1995). However, the producers of Cambrian Rosselia are unknown as there exist no fossil evidence for Cambrian terebellids. In a model presented by Nara (1995) the organism was a surface detritus feeder that constructed the burrow walls from surface materials. On the other hand, Goldring (1996) distinguished between two mechanisms for the formation of concentrically laminated burrows, one made in response to the infilling sediment pushed aside by the producer, and a second produced by the addition of successive wall-layers by the living organism. With regard to the Desejosa material we consider it more likely that the burrow formed in response to sediment influx rather than the result of sediment manipulation from feeding activity.

\section{Ichnogenus Teichichnus Seilacher, 1955}

\section{Teichichnus rectus Seilacher, 1955 (Figs. 4A-C, 5A-C).}

Description. Retrusive spreiten-burrows with horizontal long axis. A specimen examined in a serially sectioned slab (Fig. 5A, B) has a spreite lamina that is $15 \mathrm{~cm}$ long and $3.5 \mathrm{~cm}$ high. The base of the lamina is gently inclined with a difference of close to $2 \mathrm{~cm}$ between the preserved extremities. The spreiten are crudely developed but show a retrusive pattern (Figs. 4C; 5A, B), and spreite lamellae indicate a successive displacement along the horizontal axis (see sketch in Fig. 4).

Discussion. These trace fossils can be assigned to Teichichnus in being wall-like vertically oriented spreiten. The lamellae are somewhat irregular but the burrows can be compared with material that Pacześna (1996) attributed to Teichichnus rectus from the early and middle Cambrian of Poland. Axial displacement of the spreiten is also present in the type material of Teichichnus rectus material from the late early Cambrian Kussak Formation of Pakistan (Seilacher, 1955, plate 24, fig. 1).

\section{DISCUSSION}

The ichnogenus Rosselia has been typically reported from shallow-marine deposits (Uchman and Krenmayr, 1995) and its presence with Teichichnus is indicative of the Cruziana Ichnofacies, which is representative of a shallowmarine depositional environment between fair-weather and storm wave base, consistent with earlier interpretations of the depositional conditions of the upper part of the Desejosa Formation in this sector (Sousa, 1983a, b).

The age of the Douro Group has been problematic, being referred to as ante-Ordovician and probably late Precambrian to Cambrian in previous studies (Teixeira, 1955; Teixeira et al., 1964; Teixeira, 1981; Sousa, 1982, 1983a, b, 1984; Rebelo and Romano, 1986; Ferreira da Silva and Ribeiro, 1994; Coke et al., 1995; Coke and GutiérrezMarco, 2001; Pereira et al., 2006). Brachiopods (including Lingulella major) from strata in the Serra do Marão area (Portugal) that were originally attributed to the Desejosa Formation by Teixeira et al. (1964), were considered the oldest skeletal fossils of Portugal (Teixeira, 1981). A more recent study was made by Coke and Gutiérrez-Marco (2001), who failed to recover additional brachiopods from the Desejosa Formation in the Marão area, and remarked on inconsistencies in the locality description provided in the reports of these specimens. Sá et al. (2002) reported on the recovery of some of the type material of $L$. major, until that time thought to be lost. They concluded that the rock matrix is identical to that of the Ordovician "Quartzitos sem Ferro" formation (Marão Formation in Sá et al., 2003, 2005) cropping out in the same area.

The poorly preserved trilobites described by Rebelo and Romano (1986) are then the only fossil evidence for Phanerozoic age for the upper part of Desejosa Formation. This is now corroborated by the new discovery of trace fossils described here, as discussed below.

Trace fossils can be used to differentiate Phanerozoic and pre-Phanerozoic rocks, with some ichnogenera offering an additional age precision. The appearance of trace fossil genera through the Ediacaran-Cambrian boundary and into the Cambrian, led to an ichnofossil-based zonation (e.g. MacNaughton, 2007; Buatois and Mángano, 2011). The ichnotaxa described from the Desejosa Formation can be considered within this zonation. The ichnogenus 
Teichichnus is an indicator for Cambrian (or later) age (e.g. Crimes, 1987; McIlroy et al., 1998). In Newfoundland the first appearance of Teichichnus belongs to the second Cambrian trace fossil-based zone - Rusophycus avalonensis Zone - and closely follows the appearance of Rusophycus. In the East European Platform, Teichichnus is common in the Lontova horizon, whereas there are no clear reports from the basal Cambrian Rovno horizon. The presence of Teichichnus point to an age of ca. 530Ma, or younger, with no additional precision.

The ichnogenus Rosselia is known from the early Cambrian to the Holocene (e.g. Nara and Haga, 2007), but early Palaeozoic examples are scarce, with the first appearance of this ichnogenus being poorly constrained. In order to assess the potential ichnostratigraphic implications of Rosselia we have undertaken a literature review of Cambrian occurrences of Rosselia and Cylindrichnus (Table I, Electronic Appendix available at www.geologica-acta.com). Direct comparison of the Rosselia found in the Desejosa Formation with the previously reported Cambrian localities is complicated by the general lack of cut material in those studies. Examples of early Cambrian Rosselia are frequently cited specimens from the Kussak Formation in Pakistan (Seilacher, 1955), being assigned to the Cambrian Stage 4. However, this author noted that the conical structure seemed to be connected to a vertical burrow and therefore this material could only be cautiously compared to Rosselia. Although Seilacher (1955) described Rosselia as abundant, we are not aware of any additional documentation of this material. Examples of Rosselia with sand-rich laminae were reported by Desjardins et al. (2010a, b) from the Lake Louise and St. Iran formations of the Gog Group, Alberta, Canada. These affected planar and hummocky cross-stratified sandstones with an upwards-flaring laminae and a cylindrical central shaft. The age of this group is constrained by acritarchs from the lower part of the St. Piran Formation that Downie (1982) compared to those of the Lükati horizon of the East European Platform (Cambrian Stage 3). Belaústegui and Gibert (2009) suggested that Cylindrichnus operosus (Orłowski, 1990) from the lower Cambrian of Poland is better assigned to Rosselia. Also, the Cylindrichnus concentricus reported from the middle Cambrian of Poland by Pacześna (1996) is comparable to the Rosselia described here. There exist no previous reports of Rosselia from the Cambrian of Iberia, although there are several reports of Cylindrichnus especially in the middle Cambrian. The previous, earliest descriptions of Iberian occurrences of Rosselia were made in the upper and middle part of the Early Ordovician (Floian) in the Serra do Brejo Formation in Figueiró dos Vinhos, Portugal (Cooper and Romano, 1982). This material is in a facies sandier than that of Desejosa Formation but it can be compared to the material described here. The Rosselia of Desejosa Formation represents some of the finest examples of Cambrian Rosselia ichnogenus with clearly defined concentric muddy laminae.

The presence of Rosselia $\mathrm{cf}$. socialis in the upper part of the Desejosa Formation combined with the earlier findings of indeterminable trilobites in a similar stratigraphic position, means that this part of the succession cannot be older than Cambrian Age 3 (ca. 522Ma). However, the stratigraphic relationships in the Desejosa Formation between the Rosselia and the trilobite localities are not clear, due to the strongly erosive Toledanic Unconformity which is topping Desejosa Formation in Açoreira village (at $20 \mathrm{~km}$ to the west of this ichnofossil site), were Rebelo and Romano (1986) found the trilobite remains. At present, the upper age limit of the Douro Group has to be based on lithostratigraphic correlation to units within the Spanish part of the CIZ. Sousa (1983a, b, 1984) suggested that much of the Douro Group can be correlated with the Aldeatejada Formation (Díez Balda, 1986) in the Salamanca area and the Pusa Formation (San José, 1983) in the Toledo Mountains. Similarly, Pereira et al. (2006) approximated the top of the Douro Group to the upper part of the Pusa Formation and parts of the Azorejo Formation (San José et al., 1974), which they positioned close to the transition of the Cordubian-Ovetian regional stages. A somewhat younger age for the upper part of the Pusa Formation was suggested by Jensen et al. (2010), placing it firmly within the Ovetian (Cambrian Stage 3). A circumstantial argument against a higher position of Desejosa Formation is the absence of prominent carbonate beds in the upper part of the Douro Group.

\section{CONCLUSIONS}

We present the first detailed description of discrete trace fossils from the Desejosa Formation on the basis of material from a new locality in the Freixo de Espada à Cinta area, Portugal. The most reliably identified forms are Teichichnus rectus and Rosselia cf. socialis, being the first report of the ichnogenus Rosselia from the Cambrian of Iberia, and some of the most conspicuous Cambrian examples of this ichnogenus to date.

A review of Cambrian occurrences of Rosselia and other vertical concentrically laminated burrows, show no record older than Cambrian Age 3. Together with the additional evidence of the previously described scarce remnants of unidentified trilobites, this demonstrates that the upper part of the Desejosa Formation is no older than Cambrian Age 3. Also the ichnogenera association (Cruziana Ichnofacies) described in this paper gives evidences of a shallow water depositional environment between fair-weather and storm wave base. 
The Desejosa Formation is conformably overlain by a recently proposed lithostratigraphic unit, called Montes Ermos (Fig. 2). This is younger than the Cambrian Age 3 with no further precision. Nevertheless the absence of middle and late Cambrian rocks in the CIZ points to an age towards the later part of the early Cambrian. An upper age constraint for both formations is provided by the unconformably overlying Early Ordovician rocks.

\section{ACKNOWLEDGMENTS}

ÍDS acknowledges the Instituto Geológico y Minero de España (IGME) for a PhD scholarship "Formación de Personal Investigador" and the institutional support provided and to the project CGL2010-18905/BTE. SJ acknowledges funding from the Spanish Ministry of Science and Innovation through grants CGL2008-0473 and CGL-2012-37237 (both co-financed by Fondo Europeo de Desarrollo Regional [FEDER]). The manuscript benefited from the reviews of Masakazu Nara and an anonymous reviewer. This work is a contribution to the IGCP project $\mathrm{n}^{\circ} 597$ - Amalgamation and breakup of Pangaea.

\section{REFERENCES}

Aceñolaza, G.F., Nieva, S.M., 2003. Caracteres estratigráficos e icnológicos de la Formación Candelaria (CambroOrdovícico) aflorante en el NE de la Provincia de Tucumán. Revista de la Asociación Geológica Argentina, 58, 434-446. Belaústegui, Z., Gibert, J.M.de., 2009. Icnofábrica de Cylindrichnus en el Mioceno de la costa de Tarragona (Cataluña, España). Paleolusitana, 1, 97-104.

Belaústegui,Z., Gibert,J.M.de., 2013. Bow-shaped, concentrically laminated polychaete burrows: A Cylindrichnus concentricus ichnofabric from the Miocene of Tarragona, NE Spain. Palaeogeography, Palaeoclimatology, Palaeoecology, 381382, 119-127.

Brasier, M.D., Perejón, A., San José, M.A., 1979. Discovery of an important fossiliferous Precambrian-Cambrian sequence in Spain. Estudios Geológicos, 35, 379-383.

Buatois, L.A., Mángano, M.G., 2011. Ichnology: The role of organism-substrate interactions in space and time. Cambridge, Cambridge University Press, 358pp.

Carrington da Costa, M., 1950. Notícia sobre uma carta geológica do Buçaco de Nery Delgado. Comunicações dos Serviços Geológicos de Portugal, 1-28.

Coke, C., 2000. Litostratigrafia do Ordóvicico inferior do ramo sul do Serra da Marão, Norte de Portugal. Comunicações do Instituto Geológico e Mineiro, 87, 13-34.

Coke, C., Gutierrez Marco, J. C., 2001. Braquiópodos Linguliformea del Ordovícico Inferior de la Serra do Marão (Zona Centroibérica, N de Portugal). Boletín Geológico y Minero, 112, 33-50.

Coke, C., Pires, C.A.C., Sousa, M.B., 1995. A Base do
Ordovícico no autóctone da Serra do Marão e sua relação com o Câmbrico. In: Rodríguez Alonso, M.D., Gonzalo Corral, J.C. (eds.). Comunicaciones XIII Reunión de Geologia del Oeste Peninsular. Salamanca, Reunión anual del PICG-319 e Encuentro Regional del PICG-320, 54-58.

Coke, C., Dias, R., Ribeiro, A., 2000. Evolução geodinâmica da bacia do Douro durante o Câmbrico e Ordovícico inferior: um exemplo de sedimentação controlada pela tectónica. Comunicações Geológicas, 87, 5-12.

Cooper, A.H., Romano, M., 1982. The Lower Ordovician stratigraphy of the Dornes - Figueiró dos Vinhos area, Central Portugal, with descriptions of Merostomichnites ichnosp. and Rosselia socialis, two previously unrecorded trace fossils. Comunicações dos Serviços Geológicos de Portugal, 68, 73-82.

Cortijo, I., Martí Mus, M., Jensen, S., Palacios, T., 2010. A new species of Cloudina from the terminal Ediacaran of Spain. Precambrian Research, 176, 1-10.

Crimes, T.P., 1987. Trace fossils and correlation of late Precambrian and early Cambrian strata. Geological Magazine, 124, 97-119.

Dahmer, G., 1937. Lebensspuren aus dem Taunusquarzit und den Siegener Schichten (Unterdevon). Preussischen Geologischen Landesanstalt zu Berlin Jahrbuch 1936, 57, 523-539.

Desjardins, P.R., Mángano, M.G., Buatois, L.A., Pratt, B.R., 2010a. Skolithos pipe rock and associated ichnofabrics from the southern Rocky Mountains, Canada: colonization trends and environmental controls in an early Cambrian sand-sheet complex. Lethaia, 43, 507-528.

Desjardins, P.R., Pratt, B.R., Buatois, L.A., Mángano, M.G., 2010b. Stratigraphy and sedimentary environments of the Lower Cambrian Gog Group in the southern Rocky Mountains of Western Canada: transgressive sandstones on a broad continental margin. Bulletin of Canadian Petroleum Geology, 58, 403-439.

Dias da Silva, Í., González Clavijo, E., Barba, P., Valladares, M.I., Ugidos, J.M., 2011. Geochemistry of Lower Palaeozoic shales. A case study in a sector of the Iberian Variscides. In: Gutiérrez Marco, J.C., Rábano, I., García-Bellido, D. (eds.). 11th International Symposium on the Ordovician System, Alcalá de Henares, Ordovician of the World. Madrid, Instituto Geológico y Minero de España, 121-125.

Dias da Silva, Í., 2014. Geología de las Zonas Centro Ibérica y Galicia - Trás-os-Montes en la parte oriental del Complejo de Morais, Portugal/España. Nova Terra, Coruña, Instituto Universitario de Geología "Isidro Parga Pondal" - Área de Xeoloxía e Minería do Seminario de Estudos Galegos, 45, 424pp.

Dias, R., Coke, C., Ribeiro, A., 2006. Da Deformação na Serra do Marão ao zonamento do autóctone da Zona CentroIbérica. In: Dias, R., Araújo, A., Terrinha, P., Kullberg, J.C. (eds.). Geologia de Portugal no Contexto da Ibéria. Évora, Universidade de Évora, 35-61.

Díez Balda, M.A., 1986. El Complejo Esquisto-Grauváquico, las series paleozoicas, la estructura hercínica al Sur de Salamanca. $\mathrm{PhD}$ Thesis. Salamanca, Universidad de Salamanca, 162pp. 
Díez Balda, M.A., Rodríguez Alonzo, M.D., Liñan, E., Gámez Vintaned, J.A., López Díaz, F., Moreno, F., Moreno-Eiris, A., Perejon, A., Pieren, A. P., Martínez Poyatos, D., Vegas, R., 2004. La transgresión cámbrica. In: Vera, J.A. (ed.). Geología de España. Madrid, Sociedad Geológica de España-Instituto Geológico y Minero de España, 81.

Downie, C., 1982. Lower Cambrian acritarchs from Scotland, Norway, Greenland and Canada. Transactions of the Royal Society of Edinburgh, Earth Sciences, 72, 257-285.

Escuder Viruete, J., Arenas, R., Martínez Catalán, J. R., 1994. Tectonothermal evolution associated with Variscan crustal extension, in the Tormes Gneiss dome (NW Salamanca, Iberian Massif, Spain). Tectonophysics, 238, 117-138.

Escuder Viruete, J., Díez Montes, A., Carrasco, R., Sanz Santos, M.A. 2000. Mapa y Memoria explicativa de la hoja $N^{\circ} 422$ (Aldeadávila de la Ribera). Mapa Geológico de España a escala 1:50.000. Madrid, Instituto Tecnológico Geominero de España.

Ferreira da Silva, A., Ribeiro, M.L., 1994. Notícia Explicativa da Folha 15-B (Freixo de Espada à Cinta) da Carta Geológica de Portugal à Escala 1:50.000. Lisboa, Instituto Geológico e Mineiro.

Frey, R.W., Howard, J.D., 1985. Trace fossils from the Panther Member, Star Point Formation (Upper Cretaceous), Coal Creek Canyon, Utah. Journal of Paleontology, 59, 370-404.

Gámez Vintaned, J.A., Mayoral Alfaro, E., 1995. Paleoicnología del grupo Mesones (Cámbrico Inferior-Medio) en Murero (Cadena Ibérica Occidental NE de España), In: Gámez Vintaned, J.A., Liñán, E. (eds.). La expansión de la vida en el Cámbrico. Libro homenaje al Prof. Klaus Sdzuy. Memorias de las IV Jornadas Aragonesas de Paleontología, 219-252.

Gámez Vintaned, J.A., Mayoral, E., Gozalo, R., 2000. Lower and Middle Cambrian trace fossils from the Lancara and Oville formations in the area of Presa del Porma (Cantabrian Zone, northern Spain). Insugeo, Serie Miscelánea, 6, 91-94.

Gámez Vintaned, J.A., Liñán, E., Mayoral, E., Díez, M.E., Gozalo, R., Muñiz, F., 2006. Trace and soft body fossils from the Pedroche Formation (Ovetian, Lower Cambrian of the Sierra de Córdoba, S Spain) and their relation to the Pedroche event. Geobios, 39, 443-468.

Goldring, R., 1996. The sedimentological significance of concentrically laminated burrows from Lower Cretaceous Ca-bentonites, Oxfordshire. Journal of the Geological Society, 153, 255-263.

Gozalo, R., Liñan, E., Palacios, T., Gámez Vintaned, J.A., Mayoral, E., 2003. The Cambrian of the Iberian Peninsula: an overview. Geologica Acta, 1(1), 103-112.

Gutiérrez Marco, J.C., San José, M.A., Pieren, A.P., 1990. Post-Cambrian Paleozoic stratigraphy, In: Dallmeyer, R.D., Martínez García, E. (eds.). Pre-Mesozoic Geology of Iberia. Germany, Springer-Verlag, 160-171.

Hofmann, R., Mángano, M.G., Elicki, O., Shinaq, R. 2012: Paleoecologic and biostratigraphic significance of trace fossils from shallow- to marginal marine environments from the Middle Cambrian (Stage 5) of Jordan. Journal of Palaeontology, 86, 931-955.
Jensen, S., 1997. Trace fossils from the Lower Cambrian Mickwitzia sandstone, south-central Sweden. Fossils and Strata, 42, 1-111.

Jensen, S., 2003. The Proterozoic and Earliest Cambrian trace fossil record: patterns, problems and perspectives. Integrative and Comparative Biology, 43, 219-228.

Jensen, S., Palacios, T., Martí Mus, M., 2010. Revised biochronology of the Lower Cambrian of the Central Iberian Zone, southern Iberian massif, Spain. Geological Magazine, 147, 690-703.

Julivert, M., Fonboté, J.M., Ribeiro, A., Conde, L., 1972. Memoria explicativa del Mapa Tectónico de la Península Ibérica y Baleares. Escala 1:1.000.000. Madrid, Instituto Geológico y Minero de España, 113pp.

Liñan, E., Álvaro, J., Gozalo, R., Gámez Vintaned, J.A., Palacios, T., 1995. El Cámbrico Medio de la Sierra de Córdoba (Ossa-Morena, S de España): trilobites y paleoicnología. Implicaciones bioestratigráficas y paleoambientales. Revista Española de Paleontología, 10, 219-238.

Lotze, F. 1945. Zur gliederung der Varisziden der Iberishcen Meseta. Geotektonische Forschungen, 6, 78-92.

MacNaughton, R.B., 2007. The application of trace fossils to biostratigraphy. In: Miller, W. (ed.). Trace Fossils. Concepts, Problems, Prospects, 135-148.

Mángano, M.G., Buatois, L.A., Hofmann, R., Elicki, O., Shinaq, R., 2013. Exploring the aftermath of the Cambrian explosion: The evolutionary significance of marginal- to shallow-marine ichnofaunas of Jordan. Palaeogeography, Palaeoclimatology, Palaeoecology, 374, 1-15.

Mata, S.A., Corsetti, C.L., Corsetti, F.A., Awramik, S.M., Bottjer, D.J., 2012. Lower Cambrian anemone burrows from the upper member of the Wood Canyon Formation, Death Valley region, United States: Paleoecological and Paleoenvironmental significance. PALAIOS, 27, 594-606.

McIlroy, D., Brasier, M.D., Moseley, J.B., 1998. The ProterozoicCambrian transition within the 'Charnian Supergroup' of central England and the antiquity of the Ediacara fauna. Journal of the Geological Society, 155, 401-411.

Medina, J., Rodríguez-Alonso, M.D., Alonso-Gavilán, G., 1998. Sedimentação em plataforma siliciclástica do Grupo das Beiras (CXG) na região do Caramulo-Buçaco (Portugal central). Comunicações do Instituto Geológico e Mineiro, 85, 39-71.

Nara, M., 1995. Rosselia socialis: A dwelling structure of a probable terebellid polychaete. Lethaia, 28, 171-178.

Nara, M., 1997. High-resolution analytical method for event sedimentation using Rosselia socialis. PALAIOS, 12, 489494.

Nara, M., Haga, M., 2007. The youngest record of trace fossil Rosselia socialis: Occurrence in the Holocene shallow marine deposits of Japan. Paleontological Research, 11, 21-27.

Orłowski, S., 1990. Trace fossils in the Lower Cambrian sequence in the Świętokrzyskie Mountains, central Poland. Acta Palaeontologica Polonica, 34, 211-231.

Otto, E. von, 1854. Additamente zur Flora des Quadergebirges in Sachsen. Leipzig, Heft, 2, 53pp. 
Pacześna, J., 1996. The Vendian and Cambrian ichnocoenoses of Lublin Region. Prace, Państwowego Instytutu Geologiczny, 355pp.

Pereira, E., Pereira, D.Í., Rodrigues, J.F., Ribeiro, A., Noronha, F., Ferreira, N., Sá, C.M.d., Ramos, J.M.F., Moreira, A., Oliveira, A.F., 2006. Notícia Explicativa da Folha 2 da Carta Geológica de Portugal à Escala 1:200.000. Lisboa, Instituto Nacional de Engenharia, Tecnologia e Inovação, 119pp.

Pereira, M.F., Solá, A.R., Chichorro, M., Lopes, L., Gerdes, A., Silva, J.B., 2012a. North-Gondwana assembly, break-up and paleogeography: $\mathrm{U} / \mathrm{Pb}$ isotope evidence from detrital and igneous zircons of Ediacaran and Cambrian rocks of SW Iberia. Gondwana Research, 22, 866-881.

Pereira, M.F., Linnemann, U., Hofmann, M., Chichorro, M., Solá, A.R., Medina, J., Silva, J.B., 2012b. The provenance of Late Ediacaran and Early Ordovician siliciclastic rocks in the Southwest Central Iberian Zone: Constraints from detrital zircon data on northern Gondwana margin evolution during the late Neoproterozoic. Precambrian Research, 192-195, 166-189.

Pérez-Estaún, A., Bea, F., Bastida, F., Marcos, A., Martínez Catalán, J. R., Martínez Poyatos, D., Arenas, R., Díaz García, F., Azor, A., Simancas, J.F., González Lodeiro, F., 2004. La Cordillera Varisca Europea: El Macizo Ibérico. In: Vera, J.A. (ed.). Geología de España. Madrid, Sociedad Geológica de España-Instituto Geológico y Minero de España, 22-24.

Pickerill, R.K., Peel, J.S., 1990. Trace fossils from the Lower Cambrian Bastion Formation of North-East Greenland. Grønlands Geologiske Undersøgelse, 147, 5-43.

Rebelo, J.A., Romano, M., 1986. A contribution to the lithostratigaphy and palaeontology of the Lower Palaeozoic rocks of the Moncorvo Region, Northeast Portugal. Comunicações dos Serviços Geológicos de Portugal, 72, 45-57.

Rodríguez Alonso, M.D., Díez Balda, M.A., Perejón, A., Pieren, A.P., Liñán, E., López Díaz, F., Moreno, F., Gámez Vintaned, J.A., González Lodeiro, F., Martínez Poyatos, D., Vegas, R., 2004. La Secuencia estratigráfica del NeoproterozoicoCámbrico Inferior. In: Vera, J.A. (ed.). Geología de España. Madrid, SGE-IGME, 78-81.

Sá, A.A., Meireles, C., Carlos, C., Gutiérrez-Marco, J.C., 2005. Unidades litoestratigráficas do Ordovícico da região de Trásos-Montes (Zona Centro Ibérica). Comunicações Geológicas, 92, 31-74.

Sá, A.A., Coke, C., Piçarra, J.M., 2002. Redescoberta do material tipo de "Lingulella" major Teixeira, Ribero, Silva 1964 (braquiópode quitinofosfático) e as suas implicações estratigráficas para o Paleózico do norte de Portugal. In: Civis, J., González Delgado, J.A. (eds.). Libro de Resumenes de la XVIII Jornada de la Sociedad Española de Paleontología e II Congreso Ibérico de Paleontología. Salamanca, Universidad de Salamanca, 136-137.

Sá, A.A., Meireles, C., Coke, C. G., Gutiérrez-Marco, J.C., 2003. Reappraisal of the Ordovician stratigraphy and paleontology of Trás-os-Montes (Central Iberian Zone, NE Portugal). In:
Albanesi, G.I., Beresi, M.S., Peralta, S.H. (eds.). Ordovician from the Andes. Tucumán, Universidad Nacional de Tucumán, 113-136.

San José, M.A., Peláez Pruneda, J.R., Vilas, L., Herranz Araujo, P., 1974. Las series ordovícicas y preorodovícicas del sector central de los Montes de Toledo. Boletín Geológico y Minero, 85, 21-31.

San José, M.A., 1983. El Complejo sedimentario pelíticograuváquico. In: Comba, J.A. (ed.). Geología de España, Libro Jubilar J.M. Ríos. Madrid, Instituto Geológico y Minero de España, 1, 91-99.

San José, M.A., Pieren, A.P., García-Hidalgo, J.F., Vilas, L., Herranz, P., Peláez, J.R., Perejon, A., 1990. Ante-Ordovician Stratigraphy. In: Dallmeyer, R.D., Martínez García, E. (eds.). Pre-Mesozoic Geology of Iberia. Germany, Springer-Verlag, 147-159.

Schlirf, M., Nara, M., Uchman, A., 2002. InvertebratenSpurenfossilien aus dem Taunusquarzit (Siegen, Unterdevon) von der "Rossel" nahe Rüdesheim. Jahrbuch des Nassauischen Vereins für Naturkunde, 23, 43-63.

Seilacher, A., 1955. Spuren und Fazies im Unterkambrium. In: Schindewolf, O.H., Seilacher, A. (eds.). Beiträge zur Kenntniss des Kambriums in der Salt Range (Pakistan). Akademie der Wissenschaften und der Literatur, Mainz, Abhandlungen der Mathematisch-Naturwissenschaftlichen Klasse 1955, 373-399.

Sousa, M.B., 1982. Litoestratigrafia e estrutura do Complexo Xisto-Grauváquico - Grupo do Douro (NE de Portugal). $\mathrm{PhD}$ Thesis. Coimbra, Universidade de Coimbra, unpublished, 222pp.

Sousa, M.B., 1983a. Litostratigrafia do CXG - Grupo do Douro (NE Portugal). Coimbra, Universidade de Coimbra, Memórias e Notícias do Museu do Laboratório de Mineralogia e Geologia, 95, 3-63.

Sousa, M.B., 1983b. Considerações paleogeográficas e ensaio de correlacão da formacões do grupo do Douro (CXG) com as formacões ante-Ordovícicas da Zona CentroIbérica. Coimbra, Universidade de Coimbra, Memórias e Notícias do Museu do Laboratório de Mineralogia e Geologia, 96, 65-98.

Sousa, M.B., 1984. Considerações sobre a estratigrafia do Complexo Xisto-Grauváquico (CXG) e sua relação com o Paleozoico Inferior. Cuadernos Geología Ibérica, 9, 9-36.

Teixeira, C., 1955. Notas sobre a Geologia de Portugal: O Complexo Xisto-Grauváquico ante-Ordovícico. Porto Editora, 50pp.

Teixeira, C., 1981. Geologia de Portugal, Vol. I. Precâmbrico, Paleozóico. Lisboa, Fundação Calouste Gulbenkian, 659pp.

Teixeira, C., Ribeiro, A., da Silva, L.C., 1964. La faune de Lingulellinae des formations anté-ordoviciennes de Marão. Boletim da Sociedade Geológica de Portugal, 15, 117-122.

Uchman, A., Krenmayr, H.G., 1995. Trace fossils from Lower Miocene (Ottnangian) molasse deposits of Upper Austria. Paläontologische Zeitschrift, 69, 503-524. 
Valladares, M.I., Barba, P., Ugidos, J.M., 2002. Precambrian. In: Gibbons, W., Moreno, M.J. (eds.). The Geology of Spain. London, Geological Society, 8-16.

Vidal, G., Jensen, S., Palacios, T., 1994a. Neoproterozoic (Vendian) ichnofossils from Lower Alcudian strata in central Spain. Geological Magazine, 131, 169-179.
Vidal, G., Palacios, T., Gámez-Vintaned, J.A., Díez Balda, M.A., Grant, S.W.F., 1994b. Neoproterozoic-early Cambrian geology and paleontology of Iberia. Geological Magazine, 131, 729-765.

Manuscript received May 2013;

revision accepted March 2014;

published Online May 2014. 


\section{ELECTRONIC APPENDIX I}

TABLE I. Cambrian occurrences of Rosselia and Cylindrichnus

\begin{tabular}{|c|c|c|c|c|c|}
\hline Original attribution & Reference & Stratigraphy and location & Chronostratigraphy & Characteristics & Comment \\
\hline \multirow{3}{*}{ Rosselia isp. } & $\begin{array}{l}\text { Desjardins et al., } \\
\text { 2010a, b }\end{array}$ & $\begin{array}{l}\text { St Piran Fm., Gog Group, } \\
\text { Alberta, Canada }\end{array}$ & $\begin{array}{l}\text { Cambrian Stage 3, on } \\
\text { acritarchs }\end{array}$ & $\begin{array}{l}\text { Funnel-shaped concentric laminae, to } 5 \mathrm{~cm} \text { wide, } \\
\text { sand-filled central tube }\end{array}$ & Abundant \\
\hline & Mángano et al. 2013 & Hanneh Mbr, Jordan & Cambrian Stage 5 & - & - \\
\hline & $\begin{array}{l}\text { Aceñolaza and } \\
\text { Nieva, } 2003\end{array}$ & Candelaria Fm., Argentina & Furongian-Lower Ord. & - & - \\
\hline cf. Rosellia isp. & Seilacher, 1955 & $\begin{array}{l}\text { Kussak Fm. (Neobolus } \\
\text { beds), Pakistan }\end{array}$ & Cambrian Stage 4 & Nested laminae on top of cylindrical shaft & $\begin{array}{l}\text { Seilacher (1955) thought } \\
\text { attribution to Rosselia, doubtful }\end{array}$ \\
\hline \multirow{2}{*}{ Rosselia socialis } & $\begin{array}{l}\text { Pickerill and Peel, } \\
1990\end{array}$ & $\begin{array}{l}\text { Bastion Fm. (lower) } \\
\text { Greenland }\end{array}$ & Cambrian Stage 3 or 4 & $\begin{array}{c}\text { Funnel-shaped, } 1.15 \mathrm{~cm} \text { at top, } 0.4 \mathrm{~mm} \text { at base } \\
2 \mathrm{~cm} \text { long (incomplete). Concentric laminae } \\
\text { throughout }\end{array}$ & Three specimens \\
\hline & Jensen, 1997 & $\begin{array}{l}\text { Mickwitzia sandstone mbr., } \\
\text { File Haidar Fm., Sweden }\end{array}$ & Cambrian Stage 4 & $\begin{array}{c}\text { Conical to bulbuous, } 25-47 \mathrm{~mm} \text { wide, up to } 30 \mathrm{~mm} \\
\text { long, central tube } 3 \mathrm{~mm}\end{array}$ & - \\
\hline Cylindrichnus isp. & $\begin{array}{l}\text { Pickerill and Peel, } \\
1990\end{array}$ & $\begin{array}{l}\text { Bastion Fm. (lower) } \\
\text { Greenland }\end{array}$ & Cambrian Stage 3 or 4 & $\begin{array}{l}\text { Cylindrical } 5.1 \text { and } 4.2 \mathrm{~mm} \text { wide, with less than } 1 \\
\mathrm{~mm} \text { thick laminae }\end{array}$ & $\begin{array}{l}\text { Two specimens. Only observed } \\
\text { in positive epirelief. Length } \\
\text { unknown }\end{array}$ \\
\hline \multirow[t]{3}{*}{$\begin{array}{l}\text { Cylindrichnus } \\
\text { operosus }\end{array}$} & Orłowski, 1990 & Ociesęki Fm., Poland & Cambrian Stage 3 or 4 & $\begin{array}{l}\text { Subconical, up to } 25 \mathrm{~mm} \text { wide, with } 7 \mathrm{~mm} \text { wide and } \\
\qquad 9 \mathrm{~cm} \text { long central tube }\end{array}$ & $\begin{array}{l}\text { Rosselia - Belaustegui and } \\
\text { Gibert (2009) }\end{array}$ \\
\hline & $\begin{array}{l}\text { Gámez Vintaned et } \\
\quad \text { al., } 2006\end{array}$ & $\begin{array}{l}\text { Pedroches Fm., Cordoba } \\
\text { area, Spain. }\end{array}$ & $\begin{array}{l}\text { Cambrian Stage } 3 \\
\text { (Lower Ovetian) }\end{array}$ & $\begin{array}{l}\text { Short, } 2.4-3.5 \mathrm{~mm} \text { wide. Sand-filled core } \\
\text { surrounded by fine-grained concentric laminae }\end{array}$ & Two specimens \\
\hline & $\begin{array}{l}\text { Gámez Vintaned } \\
\text { and Mayoral Alfaro, } \\
1995\end{array}$ & Valdemiedes Fm., Spain & $\begin{array}{l}\text { Cambrian Stage } 4 \text { and } \\
\text { ?5 (Mar. And Bilb.) }\end{array}$ & $\begin{array}{c}\text { Cylindrical to subcylindrical, } 7.6 \text { to } 13.7 \mathrm{~mm} \text { in } \\
\text { diameter }\end{array}$ & $\begin{array}{l}\text { Associated with Teichichnus } \\
\text { and Sericichnus }\end{array}$ \\
\hline \multirow[t]{3}{*}{$\begin{array}{l}\text { Cylindrichnus } \\
\text { concentricus }\end{array}$} & Liñán et al., 1995 & $\begin{array}{l}\text { Los Villares Fm., Cordoba } \\
\text { area, Spain }\end{array}$ & $\begin{array}{c}\text { Cambrian Stage } 5 \\
\text { (Leonian) }\end{array}$ & $\begin{array}{l}\text { Cylindrical, 1-6 mm wide, up to } 40 \mathrm{~cm} \text { long, mud- } \\
\text { rich }\end{array}$ & - \\
\hline & $\begin{array}{l}\text { Gámez Vintaned et } \\
\text { al., } 2000\end{array}$ & Oville Fm., Spain & Cambrian Series 3 & No published details & - \\
\hline & Pacześna, 1996 & $\begin{array}{l}\text { Kostryzyn and Debki Fms, } \\
\text { Poland }\end{array}$ & $\begin{array}{l}\text { Cambrian Series } 3 \\
\text { (oelandicus, parad.) }\end{array}$ & - & - \\
\hline
\end{tabular}

